\title{
Enhanced removal of nitrate from water using amine-grafted agricultural wastes
}

\author{
Mahatheva Kalaruban ${ }^{\mathrm{a}}$, Paripurnanda Loganathan ${ }^{\mathrm{a}}$, W.G. Shim ${ }^{\mathrm{a}, \mathrm{b}}$, Jaya Kandasamy ${ }^{\mathrm{a}}$, H.H. \\ $\mathrm{Ngo}^{\mathrm{a}}$, Saravanamuthu Vigneswaran ${ }^{\mathrm{a}}$
}

${ }^{a}$ Faculty of Engineering, University of Technology Sydney (UTS), P.O. Box 123, Broadway, NSW 2007, Australia

${ }^{b}$ Department of Polymer Science and Engineering, Sunchon National University, 255 Jungang-ro, Suncheon, Jeollanam-do, Republic of Korea

\begin{abstract}
Adsorption using low-cost adsorbents is a favourable water treatment method for the removal of water contaminants. In this study the enhanced removal of nitrate, a contaminant at elevated concentration affecting human health and causing eutrophication of water, was tested using chemically modified agricultural wastes as adsorbents. Batch and fixed-bed adsorption studies were performed on corn cob and coconut copra that were surface modified by amine-grafting to increase the surface positive charges. The Langmuir nitrate adsorption capacities $(\mathrm{mg} \mathrm{N} / \mathrm{g}$ ) were 49.9 and 59.0 for the amine-grafted (AG) corn cob and coconut copra, respectively at pH 6.5 and ionic strength $1 \times 10^{-3} \mathrm{M} \mathrm{NaCl}$. These values are higher than those of many commercially available anion exchange resins. Fixed-bed (15-cm height) adsorption capacities ( $\mathrm{mg} \mathrm{N} / \mathrm{g}$ ) calculated from the breakthrough curves were 15.3 and 18.6 for AG corn cob and AG coconut copra, respectively, for an influent nitrate concentration $20 \mathrm{mg} \mathrm{N} / \mathrm{L}$ at a flow velocity $5 \mathrm{~m} / \mathrm{h}$. Nitrate adsorption decreased in the presence of sulphate, phosphate and chloride, with sulphate being the most competitive anion. The Thomas model fitted well to the fixed-bed adsorption data from four repeated adsorption/desorption cycles. Plug-flow model fitted well to the data from only the first cycle.
\end{abstract}

\section{Keywords}

Nitrate; Water treatment; Agricultural wastes adsorbents; Adsorption models

\section{Introduction}

The high intake of nitrate from water by humans can cause several health problems such as vomiting, hypertension, diarrhea, respiratory tract infections, spontaneous abortions and 'blue baby' syndrome or methemoglobinemia (Fewtrell, 2004). In order to prevent these health hazards, permissible levels of nitrate in water have been recommended in many countries. The maximum nitrate limit for drinking water established by the World Health Organization is $50 \mathrm{mg} / \mathrm{L}(11.3 \mathrm{mg} \mathrm{N} / \mathrm{L})(\mathrm{WHO}, 2011)$ and Australia's maximum nitrate limit is $50 \mathrm{mg} / \mathrm{L}$ for infants up to 3 months old, and $100 \mathrm{mg} / \mathrm{L}$ for adults and children over the age of 3 months (NHMRC, 2011). Apart from such health issues, the high concentration of nitrate in water 
bodies such as rivers and lakes can cause environmental problems such as eutrophication (Camargo and Alonso, 2006).

Nitrate is a highly soluble ion and stable in water. Thus traditional water treatment methods such as lime softening and filtration are difficult to use for the removal of nitrate from water. Several nitrate removal technologies such as electro-dialysis, reverse osmosis, adsorption and chemical and biological methods have been used in water treatment (Bhatnagar and Sillanpää, 2011 and Loganathan et al., 2013). Of these, some methods (electro-dialysis, reverse osmosis) have high operational cost (Bhatnagar and Sillanpää, 2011). Biological denitrification method requires specific microorganisms and the treated water needs a post treatment due to the presence of germs and metabolic substances (Kapoor and Viraraghavan, 1997 and Samatya et al., 2006). Furthermore the process is slow and requires maintenance of optimum conditions such as temperature which are difficult. On the other hand, adsorption is an attractive method because of its cost-effectiveness, simplicity of design and ease of operation with minimal waste production (Bae et al., 2002). However, the efficiency of this method depends on the type of adsorbent used.

Agricultural wastes have been investigated as adsorbents for the removal of contaminants from waste water (Loganathan et al., 2013). Agricultural wastes are widely available at low cost with no disposal problems and therefore their use incurs low operational expense. In previous studies a number of agricultural wastes such as rice hull, sugarcane bagasse, coconut shells, wheat straw and almond shell have been tested for the removal of nitrate from water. Another advantage of using agricultural wastes as adsorbent is that when they are fully saturated with nitrate and cannot be used further for the removal of nitrate the nitrate-rich wastes can be disposed to agricultural lands to supply nitrate as fertiliser.

One of the disadvantages of using agricultural wastes in removing nitrate is that they have low adsorption capacities. However, if they are chemically or physically modified they can prove to be good adsorbents (Loganathan et al., 2013). Various methods of modification such as protonation (Chatterjee et al., 2009), metal impregnation (Kalaruban et al., 2016) and amine-grafting (Orlando et al., 2002a and Orlando et al., 2002b) have been used to increase the nitrate adsorption capacity of adsorbents. Of these, the amine grafting method is a highly efficient method for agricultural wastes where the amine groups possessing positive charges can increase the adsorption of negatively charged nitrate (Bhatnagar and Sillanpää, 2011 and Loganathan et al., 2013). For example, Orlando et al. (2002a) reported that grafting amine groups onto lignocellulosic agricultural wastes such as Moringa oleifera husk, rice husk, sugarcane bagasse, and pine bark resulted in high Langmuir nitrate adsorption capacities of $63-74 \mathrm{mg} \mathrm{NO}_{3}{ }^{-} / \mathrm{g}$. They stated that these increased adsorption capacities as a result of amine-grafting was approximately equal to that of the commercial anion exchanger, Amberlite IRA-900. Most studies on the use of agricultural wastes for nitrate removal were tested in static batch adsorption experiments ( Bhatnagar and Sillanpää, 2011 and Loganathan et al., 2013), yet only a few have been tested using dynamic fixed-bed adsorption experiment (Xing et al., 2011 and $\mathrm{Xu}$ et al., 2012). Findings from fixed-bed experiments are more relevant to real operating systems in treatment plants. 
The main objectives of the research were to: (i) study the efficiency of nitrate removal from synthetic water using amine-grafted (AG) corn cob and coconut copra in batch and fixed-bed adsorption experiments; (ii) model the batch equilibrium, batch kinetics and fixed-bed data on nitrate removal; (iii) study the effect of co-existing anions at different concentrations on the adsorption of nitrate; and (iv) investigate desorption of nitrate from the adsorbents and the regeneration of adsorbents for multiple reuse. The new aspect of the study is to test the nitrate adsorption behaviour of amine-grafted agricultural wastes in column mode dynamic system consisting of many repeated adsorption/desorption cycles which have more practical application. Further the mathematical modelling of the dynamic system used in this study has not been dealt previously for agricultural wastes. Though amine-grafting to increase the nitrate adsorption capacity is not new, previous studies on this subject were conducted mainly in static batch mode and only two studies on fixed-bed system (Xing et al., 2011 and Xu et al., 2012). However, these two column studies neither tried to model the adsorption behaviour nor considered complementary ions effects on nitrate as in our study. Corn cob was selected as an agricultural waste as corn is one of the largest grain crops cultivated in many parts of the world with an annual worldwide production of about $520 \times 10^{9} \mathrm{~kg}$ (Ioannidou et al., 2009) and corn cob waste is available in large quantities. Coconut is one of the main palm trees cultivated throughout the tropical world to produce copra which is used to make vegetable oil (Bhatnagar et al., 2010). Large quantities of copra waste are available from the total annual coconut production of about 50 million tonnes in various countries.

\section{Materials and methods}

\subsection{Materials}

Fresh corns were obtained from Paddy's Market in Sydney, New South Wales, Australia, and waste corn cobs were separated from the corn kernels. The corn cobs were cut into small pieces, washed with distilled water and heated for $24 \mathrm{~h}$ at $100{ }^{\circ} \mathrm{C}$ inside an oven. Then they were ground and sieved to a size of 300-600 $\mu \mathrm{m}$.

Fresh coconuts were also obtained from the same market and each coconut was cut into two pieces. The coconut kernels were scraped manually from these pieces and milk extracted by hand-squeezing as much as possible. The residue was kept in an oven at $100{ }^{\circ} \mathrm{C}$ for $48 \mathrm{~h}$. The dried material known as copra was ground and sieved to $300-600 \mu \mathrm{m}$.

\subsection{Material modification}

Samples of the corn cob and coconut copra $(300-600 \mu \mathrm{m})$ were surface modified by amine grafting using Orlando et al.'s method (Orlando et al., 2002b). In this method, $20 \mathrm{~g}$ corn cob or coconut copra were reacted with $200 \mathrm{~mL}$ of epichlorohydrin in $240 \mathrm{~mL} \mathrm{~N}, N$-dimethyl formamide (DMF) at $100{ }^{\circ} \mathrm{C}$ for $1 \mathrm{~h}$. Pyridine $(80 \mathrm{~mL})$ was added to the solution and stirred for $1 \mathrm{~h}$ at $100{ }^{\circ} \mathrm{C}$. Amine groups were then introduced by adding $200 \mathrm{~mL}$ of $50 \%$ dimethylamine solution. The mixture was stirred for $3 \mathrm{~h}$ at $100{ }^{\circ} \mathrm{C}$ and washed with $2 \mathrm{~L}$ 
$0.1 \mathrm{M} \mathrm{NaOH}, 0.1 \mathrm{M} \mathrm{HCl}$ and $2 \mathrm{~L}$ diluted ethanol (ethanol: water volume ratio=1:1). Finally, it was washed with a large volume of $0.1 \mathrm{M} \mathrm{NaCl}$ and heated at $100{ }^{\circ} \mathrm{C}$ for $24 \mathrm{~h}$.

\subsection{Feed solutions}

Feed solution containing nitrate was prepared for the batch experiments by dissolving ANALAR grade $\mathrm{KNO}_{3}$ in Milli-Q water to obtain a concentration of $20 \mathrm{mg} \mathrm{N} / \mathrm{L}$. Ionic strength and $\mathrm{pH}$ of the solution were maintained at $1 \times 10^{-3} \mathrm{M} \mathrm{NaCl}$ and 6.5 , respectively. For the ion competition studies, ANALAR grade $\mathrm{KH}_{2} \mathrm{PO}_{4}, \mathrm{Na}_{2} \mathrm{SO}_{4}$ and $\mathrm{NaCl}$ were added to the nitrate solution to produce the required concentrations of phosphate, sulphate and chloride. For fixed-bed adsorption studies tap water was used instead of Milli-Q water to prepare the feed solution at a concentration of $20 \mathrm{mg} \mathrm{N} / \mathrm{L}$ at $\mathrm{pH}$ of 6.5-7.5. Tap water was used because large volumes of solution for these studies were required. All experiments were conducted in synthetic solutions containing a fixed nitrate concentration and a range of complementary ions concentrations to obtain basic information on the suitability of the AG products in the adsorptive removal of nitrate. Phosphate, sulphate and chloride ions were selected for the study as they are common anions present in ground and surface waters (Akan et al., 2012, Shah and Trivedi, 2011 and Somasundaram et al., 1993). The concentrations used were in the ranges of ions generally present in these contaminated waters.

\subsection{Nitrate analysis}

Nitrate concentration was measured using an ion chromatograph (Model 790 personal IC) equipped with an auto sampler and conductivity cell detector. The ion chromatograph was cleaned before the analysis by the mobile phase solutions containing $\mathrm{Na}_{2} \mathrm{CO}_{3}$ and $\mathrm{NaHCO}_{3}$ followed by diluted sulphuric acid and Milli-Q water.

\subsection{Adsorbent characterisation}

Samples of dried corn cob, coconut copra, AG corn cob and AG coconut copra were analysed using Zeiss supra 55VP field emission model scanning electron microscope in conjunction with energy dispersion spectrometry operated at $15 \mathrm{kv}$ to determine the elemental composition. The materials' BET surface area and pore size distribution were determined using a Micrometrics 3 Flex surface characterisation analyser at $77 \mathrm{~K}$. The total nitrogen and carbon were measured using a Leco TruSpec CN instrument.

Zeta potential measurement was done to characterise the surface electrical potential of the adsorbents. Unmodified and AG corn cob and coconut copra were suspended in Milli-Q water at a dosage of $1 \mathrm{mg} / \mathrm{L}$ and $\mathrm{pH}$ adjusted to various values in the 3-8 range using diluted $\mathrm{HCl}$ and $\mathrm{NaOH}$ solutions. The flasks were shaken at $120 \mathrm{rpm}$ in a flat shaker for $3 \mathrm{~h}$ and then the zeta potential was measured on the suspensions using a Zetasizer nano instrument (Nano ZS Zen 3600, Malvern, UK). The measurements were conducted on three replicates and the means and standard errors were calculated. 


\subsection{Batch adsorption experiments}

Nitrate adsorption by the AG and unmodified corn cob and coconut copra was determined using equilibrium and kinetics adsorption experiments at room temperature $\left(24 \pm 1^{\circ} \mathrm{C}\right)$. All experiments were conducted in duplicate and the means and standard errors of the data of duplicate samples were calculated.

\subsubsection{Equilibrium adsorption}

Equilibrium adsorption experiments were conducted by adding different amounts of adsorbent $(0.1,0.2,0.3,0.4,0.5,0.6,0.7,0.8,0.9$, and $1.0 \mathrm{~g} / \mathrm{L})$ to $100 \mathrm{~mL}$ solutions containing a nitrate concentration of $20 \mathrm{mg} \mathrm{N} / \mathrm{L}$ and ionic strength of $1 \times 10^{-3} \mathrm{M} \mathrm{NaCl}$ at pH 6.5 and agitating the suspensions at a speed of $120 \mathrm{rpm}$ in a flat shaker for $24 \mathrm{~h}$. At the end of this period, the suspensions were filtered using filters with $1.2 \mu \mathrm{m}$ size openings and analysed using an ion chromatograph analyser. The amount of nitrate adsorption was calculated by subtracting the amount of nitrate in solution after adsorption from the amount of nitrate in solution before adsorption.

\subsubsection{Adsorption kinetics}

Adsorption kinetics experiments were conducted by adding an adsorbent dose of $1 \mathrm{~g} / \mathrm{L}$ to a solution containing a nitrate concentration of $20 \mathrm{mg} \mathrm{N} / \mathrm{L}$ at an ionic strength of $1 \times 10^{-3} \mathrm{M}$ $\mathrm{NaCl}$ and $\mathrm{pH} 6.5$ and agitating the samples at a speed of $120 \mathrm{rpm}$ for different time intervals. At the end of the different shaking periods, the samples were filtered and the filtrates were analysed for nitrate. The amount of nitrate adsorbed was calculated as before.

\subsection{Effect of pH on nitrate adsorption}

The experiment on the effect of $\mathrm{pH}$ on nitrate adsorption was carried out using the same procedure as described for equilibrium adsorption. The initial nitrate concentration was the same as before but only one adsorbent dose of $0.5 \mathrm{~g} / \mathrm{L}$ and initial $\mathrm{pHs}$ of $3,4,5,6,7,8$ and 9 were used. The $\mathrm{pH}$ was adjusted by adding diluted $\mathrm{HCl}$ or $\mathrm{NaOH}$. The final $\mathrm{pHs}$ were measured and these values were used to determine the relationship of $\mathrm{pH}$ and amount adsorbed.

\subsection{Complementary ions effect}

Studies on the complementary ions effect were done using different concentrations of sulphate $(20,30,50$, and $70 \mathrm{mg} \mathrm{S} / \mathrm{L})$, phosphate $(0.5,1,5,10$ and $30 \mathrm{mg} \mathrm{P} / \mathrm{L})$ and chloride (20, 30, 50 and $70 \mathrm{mg} \mathrm{Cl} / \mathrm{L})$ with a fixed dose of adsorbent $(1 \mathrm{~g} / \mathrm{L})$ and a constant concentration of nitrate $(20 \mathrm{mg} \mathrm{N} / \mathrm{L})$ at $\mathrm{pH} 6.5$. These three ions were selected for the study as they are common anions present in ground and surface waters (Akan et al., 2012, Shah and Trivedi, 2011 and Somasundaram et al., 1993). The concentrations used were in the ranges of ions generally present in contaminated ground and wastewaters. 


\subsection{Fixed-bed adsorption studies}

Fixed-bed column adsorption experiments were performed using $2 \mathrm{~cm}$ internal diameter acrylic glass columns packed with $20 \mathrm{~g}$ of modified and unmodified corn cob and coconut copra to a height of $15 \mathrm{~cm}$. Influent solution containing nitrate at a concentration of $20 \mathrm{mg} \mathrm{N} / \mathrm{L}$ was passed through the columns at a filtration velocity of $5 \mathrm{~m} / \mathrm{h}(26.6 \mathrm{~mL} / \mathrm{min})$. A peristaltic pump was used for pumping the feed water in the up-flow mode through the column. The effluent solutions were collected on an hourly basis and nitrate was examined as before.

The maximum amount of nitrate adsorption ( $\mathrm{mg}$ ) onto the fixed-bed is defined by the equation given below (Nur et al., 2015),

$$
q_{\text {total }}=\frac{Q}{1000} \int_{t=0}^{t-\text { total }} C_{a d} \cdot d t
$$

where, $C_{a d}$ is the adsorbed nitrate concentration $\left(C_{a d}=C_{0}-C_{t}\right) m g N / L$ and $Q$ is the flow velocity $(\mathrm{L} / \mathrm{min})$. $\mathrm{q}_{\text {total }}$ is equal to the area under the plot of $\mathrm{C}_{\mathrm{ad}}$ vs time and was calculated manually from the breakthrough curves using Microsoft Excel spreadsheet. The maximum adsorption capacity was calculated by dividing the maximum adsorption of nitrate by the amount of adsorbent used in the column.

\subsection{Adsorption models}

The batch and fixed-bed adsorption data were analysed using the adsorption models presented in Table 1. The procedures for the use of all the models, except the Elovich model and the axially dispersed plug-flow model, have been described in detail elsewhere (Kalaruban et al., 2016, Kim et al., 2015 and Nur et al., 2014). The procedure for the use of Elovich model was described by Riahi et al. (2013). The axially dispersed plug-flow model is described below.

Table 1. Adsorption models.

\begin{tabular}{llll}
\hline Experiment & Models & Equation & Parameters \\
\hline $\begin{array}{llll}\text { Batch } \\
\text { equilibrium }\end{array}$ & Langmuir & $q_{e}=\frac{q_{m} b C_{e}}{1+b C_{e}}$ & $\mathrm{q}_{\mathrm{m}}, \mathrm{b}$ \\
& Freundlich & $q_{e}=K_{f} C_{e}^{1 / n}$ & $\mathrm{~K}_{\mathrm{f}}, \mathrm{n}$ \\
& Sips & $q_{e}=\frac{q_{m} b C_{e}^{1 / n}}{1+b C_{e}^{1 / n}}$ & $\mathrm{q}_{\mathrm{m}}, \mathrm{b}, \mathrm{n}$ \\
& Pseudo-first order & $\frac{d q_{t}}{d t}=k_{1}\left(q_{e}-q_{t}\right)$ & \\
kinetics & Pseudo-second order & $\frac{d q_{t}}{d t}=k_{2}\left(q_{e}-q_{t}\right)^{2}$ & $\mathrm{k}_{1}, \mathrm{q}_{\mathrm{e}}$ \\
& & & $\mathrm{k}_{2}, \mathrm{q}_{\mathrm{e}}$ \\
\hline
\end{tabular}




\begin{tabular}{llll}
\hline $\begin{array}{l}\text { Column } \\
\text { kinetics }\end{array}$ & Elovich model & $\frac{d q_{\mathrm{t}}}{d t}=\alpha e^{-\beta q_{t}}$ & $\alpha, \beta$ \\
& Thomas model & $\ln \left(\frac{c_{0}}{c_{\mathrm{t}}}-1\right)=\frac{k_{T h} q_{0} M}{Q}-k_{T h} c_{0} t$ & $\mathrm{q}_{0}, \mathrm{k}_{\mathrm{Th}}$ \\
& Axially dispersed & $\frac{\partial c}{\partial t}=D_{L} \frac{\partial^{2} c}{\partial z^{2}}-v \frac{\partial c}{\partial z}-\frac{1-\varepsilon_{b}}{\varepsilon_{b}} \rho_{p} \frac{\partial q}{\partial t}$ & DL \\
plug-flow model & Initial and boundary conditions & \\
& & $0<\mathrm{z}<\mathrm{L} ; t=0 ; c=0$ \\
& $\mathrm{z}=0 ; t>\left.0 D_{L} \frac{\partial c}{\partial z}\right|_{z=0}=-v\left(\left.c\right|_{z=0^{-}}-c \mid\right.$ \\
& & $\mathrm{z}=\mathrm{L} ; t>\left.0 \frac{\partial c}{\partial z}\right|_{z=L}=0$
\end{tabular}

${ }^{*} \mathrm{C}_{\mathrm{e}}=$ equilibrium concentration of nitrate $(\mathrm{mg} \mathrm{N} / \mathrm{L}), \mathrm{q}_{\mathrm{e}}=$ amount of nitrate adsorbed per unit mass of adsorbent $(\mathrm{mg} \mathrm{N} / \mathrm{g}), \mathrm{q}_{\mathrm{m}}=$ maximum amount of nitrate adsorbed per unit mass of adsorbent $(\mathrm{mg} \mathrm{N} / \mathrm{g})$, $\mathrm{b}=$ Langmuir and Sips affinity constant $(\mathrm{L} / \mathrm{mg}), \mathrm{K}_{\mathrm{f}}=$ Freundlich constant $(\mathrm{mg} / \mathrm{g})(\mathrm{L} / \mathrm{mg})^{1 / \mathrm{n}}$, $\mathrm{n}=$ Freundlich and Sips constant, $\mathrm{q}_{\mathrm{t}}=$ amount of nitrate adsorbed at time $\mathrm{t}(\mathrm{h}),(\mathrm{mg} \mathrm{N} / \mathrm{g}), \mathrm{k}_{1}=$ rate constant of pseudo-first order $(1 / \mathrm{h}), \mathrm{k}_{2}=$ rate constant of pseudo-second order $(\mathrm{g} / \mathrm{mg} \mathrm{h}), \alpha=$ initial adsorption rate $(\mathrm{mg} / \mathrm{g} \mathrm{min}), \beta=$ related to extent of surface coverage and activation energy for chemisorption $(\mathrm{g} / \mathrm{mg}), \mathrm{k}_{\mathrm{Th}}=$ Thomas rate constant $(\mathrm{mL} / \mathrm{min} \mathrm{mg}), \mathrm{q}_{\mathrm{o}}=$ equilibrium nitrate uptake per $\mathrm{g}$ of adsorbent $(\mathrm{mg} \mathrm{N} / \mathrm{g}), \mathrm{c}_{0}=$ inlet nitrate concentration $(\mathrm{mg} \mathrm{N} / \mathrm{L}), \mathrm{c}_{\mathrm{t}}=$ outlet nitrate concentration at time $\mathrm{t}(\mathrm{mg} \mathrm{N} / \mathrm{L}), \mathrm{M}=$ mass of adsorbent $(\mathrm{g}), \mathrm{Q}=$ filtration velocity $(\mathrm{mL} / \mathrm{min}), \mathrm{t}=$ filtration time $(\mathrm{min})$, $D_{L}=$ axial dispersion coefficient $\left(\mathrm{m}^{2} / \mathrm{s}\right), c=$ nitrate concentration in the liquid phase $(\mathrm{mg} \mathrm{N} / \mathrm{L})$, $\mathrm{q}=$ nitrate concentration in the solid phase $(\mathrm{mg} \mathrm{N} / \mathrm{L}), \epsilon B=$ bed porosity, $\rho p=$ bulk density $\left(\mathrm{kg} / \mathrm{m}^{3}\right)$, $\mathrm{v}=$ fluid velocity $(\mathrm{m} / \mathrm{s})$ and $\mathrm{z}=$ bed depth $(\mathrm{m})$.

The axially dispersed plug-flow model parameters, axial dispersion coefficient, $\mathrm{D}_{\mathrm{L}}$ and film mass transfer coefficient, $\mathrm{k}_{\mathrm{f}}$ were calculated using empirical correlations given byChung and Wen (1968) (Eq. 2), Wakao and Funazkri (1978) and Luna et al. (2011) (Eq.3), respectively. In addition, the diffusion coefficient $\left(\mathrm{D}_{\mathrm{s}}\right)$ of the homogeneous surface diffusion model (HSDM) was determined by matching the simulation results with the data obtained in experimental adsorption breakthrough curve. In order to numerically solve the axially dispersed plug-flow and the HSDM equations, in this work, Nelder-Mead simplex method (Nelder and Mead, 1965), orthogonal collocation method (OCM) (Villadsen and Stewart, 1967 ) and double variable ordinary equation (DVODE) program were used.

$$
\begin{aligned}
& \frac{D_{L} \rho}{\mu}=\frac{R_{e}}{0.2+0.11 R_{e}^{0.48}} \\
& S h=2.0+1.1 S c^{1 / 3} \operatorname{Re}^{0.6}=\frac{k_{f} d_{p}}{D_{m}}
\end{aligned}
$$

where, $\rho$ is the solution density $\left(\mathrm{kg} / \mathrm{m}^{3}\right), \mu$ is the fluid viscosity $(\mathrm{kg} / \mathrm{m} \cdot \mathrm{s}), R e$ is the Reynold's number, $S h$ is the Sherwood number, $S c$ is the Schmidt number, $\mathrm{d}_{\mathrm{p}}$ is the particle diameter $(\mathrm{m})$, and $\mathrm{D}_{\mathrm{m}}$ is the aqueous-phase diffusivity $\left(\mathrm{m}^{2} / \mathrm{s}\right)$. 


\section{Results and discussion}

\subsection{Characteristics of adsorbents}

\subsubsection{Chemical composition and surface area}

The EDS data showed that the $\mathrm{N}$ content increased in the coconut copra and corn cobs after the amine modification (Table 2). The $\mathrm{Cl}$ percentage also increased because the AG materials were finally washed with large amounts of $\mathrm{NaCl}$ to remove the excess acid and alkali used in the preparation of these materials. The $\mathrm{Cl}^{-}$ions in the $\mathrm{NaCl}$ would have adsorbed onto the positive charges on the amine groups by electrostatic attraction.

Table 2. Elemental composition of adsorbents as determined by EDS and chemical combustion methods and nitrate adsorption on the adsorbents.

\begin{tabular}{lllll}
\hline Adsorbent & EDS & & $\begin{array}{l}\text { Leco chemical } \\
\text { combustion }\end{array}$ & $\begin{array}{l}\text { Batch } \\
\text { adsorption }\end{array}$ \\
\cline { 2 - 5 } & $\begin{array}{l}\text { Nitrogen } \\
(\mathrm{mg} / \mathrm{g})\end{array}$ & $\begin{array}{l}\text { Chlorine } \\
(\mathrm{mg} / \mathrm{g})\end{array}$ & $\begin{array}{l}\text { Nitrogen }(\mathrm{mg} / \mathrm{g}) \\
\text { Norn cob }\end{array}$ & $\begin{array}{l}\text { Nitrogen } \\
(\mathrm{mg} / \mathrm{g})\end{array}$ \\
\hline $\begin{array}{l}\text { AG corn cob before } \\
\text { adsorption }\end{array}$ & 141.0 & 93 & 10.3 & - \\
$\begin{array}{l}\text { AG corn cob after } \\
\text { adsorption }\end{array}$ & 163.5 & 39 & 52.6 & - \\
$\begin{array}{l}\text { N adsorbed } \\
\text { Coconut copra }\end{array}$ & 22.5 & - & 83.7 & - \\
$\begin{array}{l}\text { AG coconut copra } \\
\text { before adsorption }\end{array}$ & 113.0 & 70 & 31.1 & - \\
$\begin{array}{l}\text { AG coconut copra after } \\
\text { adsorption }\end{array}$ & 168.0 & 24 & 11.5 & - \\
N adsorbed & 55.0 & - & 89.8 & - \\
\hline
\end{tabular}

The total $\mathrm{N}$ contents of the materials estimated by chemical combustion method were much lower than those estimated by EDS. This is probably because EDS measures only the surface layer of a few micro meters of the adsorbents (Yao et al., 2011), whereas the combustion method measured the whole particle elemental composition. However, the increase in $\mathrm{N}$ content following amine grafting in the materials is approximately the same in the two methods. Xu et al. (2010) reported virtually the same amount of $\mathrm{N}$ increased $(32 \mathrm{mg} / \mathrm{g})$ after amine grafting of wheat straw using the method used in the present study.

The BET surface areas were $10.3 \mathrm{~m}^{2} / \mathrm{g}$ and $9.8 \mathrm{~m}^{2} / \mathrm{g}$ for the corn cob and AG corn cob, respectively, and $8.1 \mathrm{~m}^{2} / \mathrm{g}$ and $7.1 \mathrm{~m}^{2} / \mathrm{g}$ for the coconut copra and AG coconut copra, respectively. 


\subsubsection{Zeta potential}

The unmodified corn cob and unmodified coconut copra both had a zero point of charge (ZPC) of approximately pH 3.0 whereas the AG corn cob and AG coconut copra had ZPC greater than $\mathrm{pH} 8.5$ (Fig. 1). This shows that amine grafting of the adsorbents has changed the surface charges on the adsorbent from negative to positive in the entire $\mathrm{pH}$ range of 3 to 8.5 , which is favourable for nitrate adsorption by electrostatic forces. This is in agreement with the results of Deng et al. (2013) who found that the amine modification of rice husk increased the ZPC from $\mathrm{pH} 2.7$ to 8.5, suggesting that the net surface charge was positive up to $\mathrm{pH}$ 8.5. Xing et al. (2011) also reported that amine grafting changed the surface charge from negative to positive in wheat straw in the $\mathrm{pH}$ range of 2 to 9 .

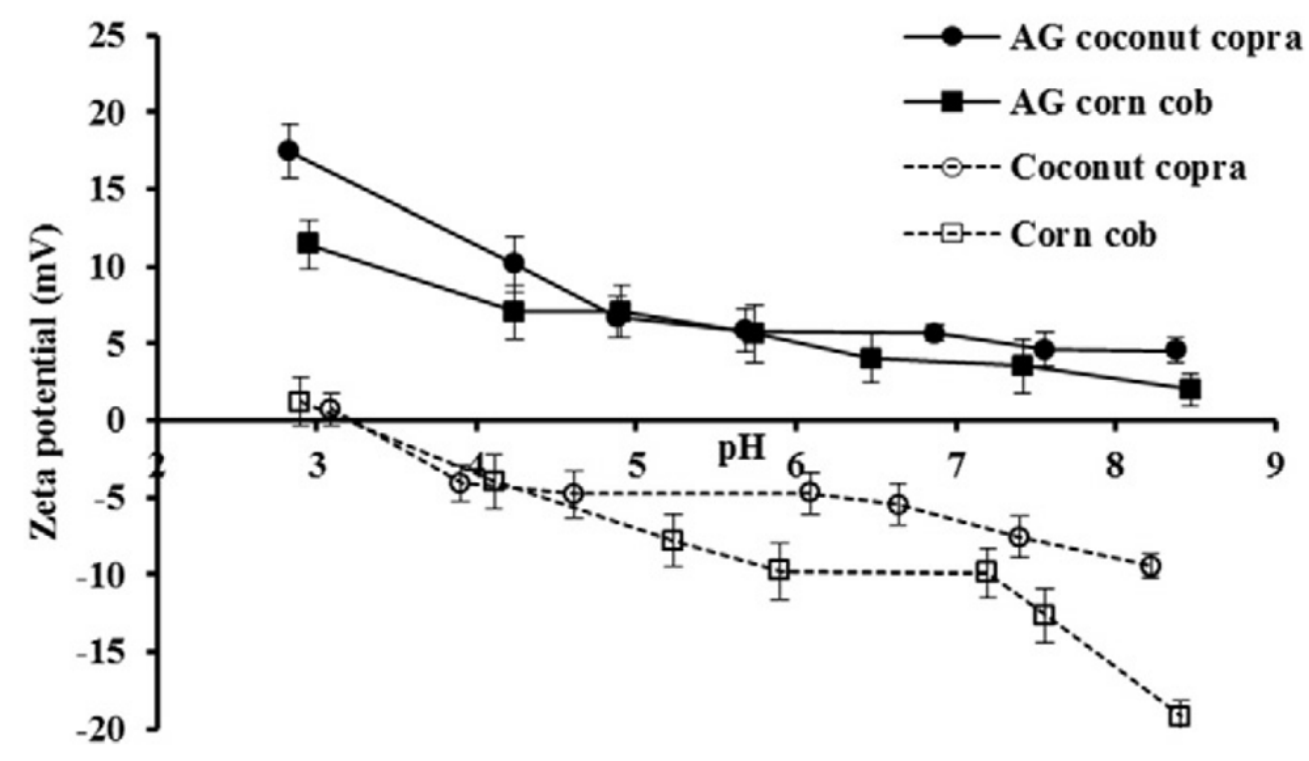

Fig. 1. Effect of $\mathrm{pH}$ on the zeta potential at the adsorbent/solution interface for corn cob, AG corn cob, coconut copra, and AG coconut copra. Vertical bars on the graphs represent standard errors of means of the data points.

\subsection{Batch adsorption studies}

\subsubsection{Effect of $\mathrm{pH}$}

The effect of $\mathrm{pH}$ on nitrate adsorption showed that for the AG materials there was no significant change in the percent adsorption in the $\mathrm{pH}$ range from 3 to 9 . The percentage adsorbed increased from $42 \%$ to $49 \%$ as the $\mathrm{pH}$ increased for the AG coconut copra and $37 \%$ to $45 \%$ for the AG corn cob. For the unmodified corn cob and the unmodified coconut copra, percentage adsorbed increased from $3 \%$ to $8 \%$ and $3 \%$ to $9 \%$, respectively. The much higher adsorption capacity of the AG materials is due to the positive surface charges produced by the amine groups (Fig. 1). The unmodified materials showed a very low percentage of adsorption because of net negative surface charges on the adsorbent surface.

\subsubsection{Adsorption isotherms}

The nitrate removal efficiencies of the AG adsorbents were much higher than those of the unmodified adsorbents (Fig. 2). Langmuir, Freundlich and Sips models were used to model 
the experiment data. The data fitted satisfactorily to all the three models (Table 3 ). The Langmuir maximum adsorption capacities for the AG coconut copra and AG corn cob were $59.0 \mathrm{mg} \mathrm{N} / \mathrm{g}$ and $49.9 \mathrm{mg} \mathrm{N} / \mathrm{g}$, respectively. The maximum adsorption capacities obtained for AG coconut copra and AG corn cob are higher than the corresponding values reported by others for amine grafted wheat straw, moringa hull, lauan sawdust, coconut husk, rice husk, pine bark and sugarcane bagasse (11-17 mg N/g; Orlando et al., 2002a and Xu et al., 2010). They are also higher than those reported for commercially available anion exchange resins such as Dowex 21K XLT (27.6 mg N/g) (Kalaruban et al., 2016), Purolite A520 E (33 mg N/g) (Nur et al., 2015) and NDP-2 (39.3 mg N/g), Purolite A 300 (33.3 mg N/g) and D201 (39.2 $\mathrm{mg} \mathrm{N} / \mathrm{g}$ ) (Song et al., 2012). The corresponding values obtained from the Sips model were $67.4 \mathrm{mg} \mathrm{N} / \mathrm{g}$ and $59.2 \mathrm{mg} \mathrm{N} / \mathrm{g}$, respectively. Nitrate adsorption on the unmodified adsorbents failed to fit the models.

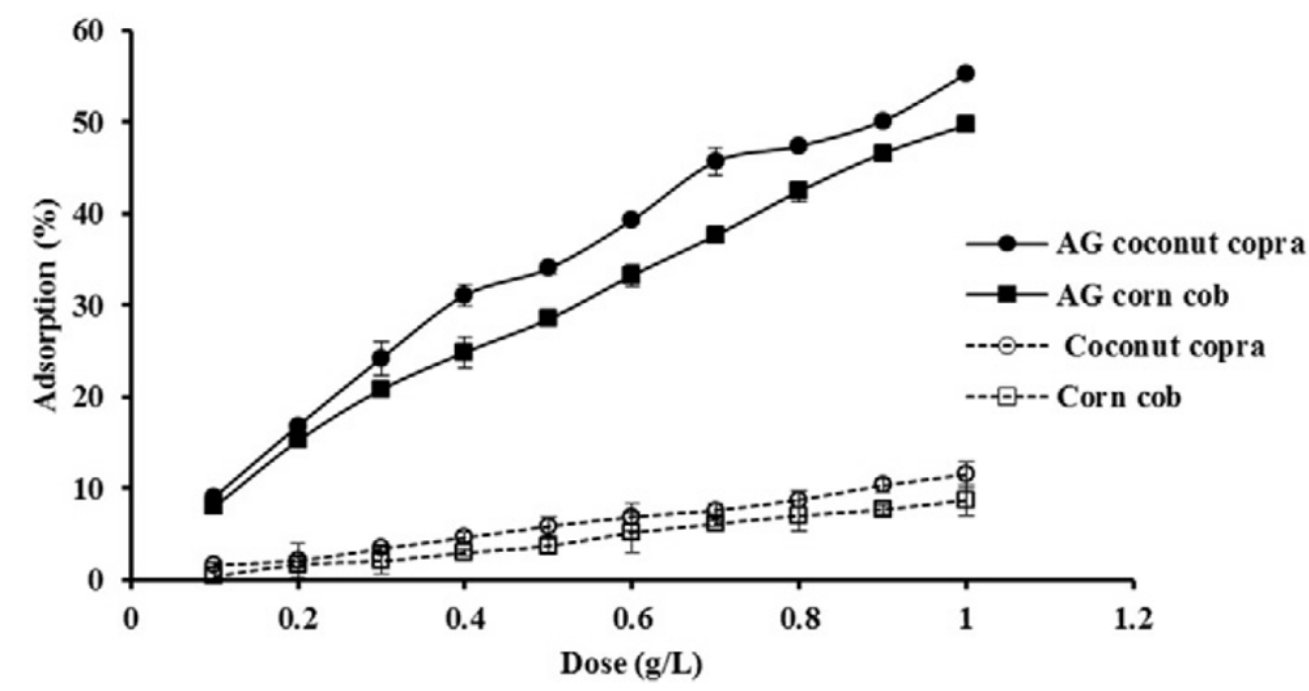

Fig. 2. Effect of adsorbent dose on the removal of nitrate at $\mathrm{pH} 6.5$ (initial nitrate concentration $20 \mathrm{mg} \mathrm{N} / \mathrm{L}$ ). Vertical bars on the graphs represent standard errors of means of the data points.

Table 3. Model parameters for the adsorption of nitrate.

\begin{tabular}{llll}
\hline Model & Parameters & AG corncob & AG coconut copra \\
\hline Langmuir & $\mathrm{q}_{\mathrm{m}}(\mathrm{mg} \mathrm{N} / \mathrm{g})$ & 49.9 & 59.2 \\
& $\mathrm{~b}(\mathrm{~L} / \mathrm{mg})$ & 0.02 & 0.02 \\
\multirow{3}{*}{ Freundlich } & $\mathrm{R}^{2}$ & 0.8769 & 0.9606 \\
& $\mathrm{k}_{\mathrm{f}}(\mathrm{mg} / \mathrm{g})(\mathrm{L} / \mathrm{mg})^{1 / \mathrm{n}}$ & 1.24 & 2.07 \\
& $\mathrm{n}$ & 1.15 & 1.33 \\
Sips & $\mathrm{R}^{2}$ & 0.9041 & 0.9615 \\
& $\mathrm{q}_{\mathrm{m}}(\mathrm{mg} \mathrm{N} / \mathrm{g})$ & 59.2 & 67.4 \\
& $\mathrm{~b}(\mathrm{~L} / \mathrm{mg})$ & 0.01 & 0.02 \\
& $\mathrm{n}$ & 1.09 & 0.96 \\
& $\mathrm{R}^{2}$ & 0.8938 & 0.9610 \\
\hline
\end{tabular}


Fig. 3 illustrates that nitrate removal efficiency drastically fell in the presence of sulphate ion and moderately decreased in the presence of phosphate and chloride ions. The adsorption occurred through the electrostatic attraction between positive surface charges on the adsorbent and negative charges on the anions by outer sphere surface complexation (nonspecific adsorption) (Loganathan et al., 2014 and Oladoja and Helmreich, 2014). Sulphate has two valance charges, and therefore it has a tendency to adsorb stronger than chloride which has one charge and phosphate which has predominantly one-charged species $\left(\mathrm{H}_{2} \mathrm{PO}_{4}{ }^{-}\right)$and some two-charged species $\left(\mathrm{HPO}_{4}{ }^{2}-\right)$ at $\mathrm{pH} 6.5$ of the study. At pH $6.5>80 \%$ phosphate is in the form of $\mathrm{H}_{2} \mathrm{PO}_{4}{ }^{-}$and the rest is in the form of $\mathrm{HPO}_{4}{ }^{2-}$ (Pan et al., 2009). The differences in the magnitude of charges in the anions have also been used by Oladoja and Ahmad (2013) to explain the differences in the competitiveness of the anions for the adsorption of $\mathrm{Cr}(\mathrm{VI})$ on binary metal oxides. Because the chloride ion has one negative charge like nitrate its competition with nitrate was significant only at high concentrations especially in corn cob. The reason for the reduced competition of the chloride at concentrations similar to nitrate is that its hydration energy is higher than that of nitrate, and lower hydration energy favours adsorption (Song et al., 2012). Phosphate's competition with nitrate was the lowest because of its low concentrations in terms of moles/L. For example, only at L5 (30 mg P/L) is its competitiveness equal to that of chloride at $\mathrm{L} 1(20 \mathrm{mg} \mathrm{Cl} / \mathrm{L})$, where the concentrations (moles/L) of the two ions are nearly equal. The extent of complementary ions competition with nitrate may vary according to wastewater conditions and the concentration of complementary ions.
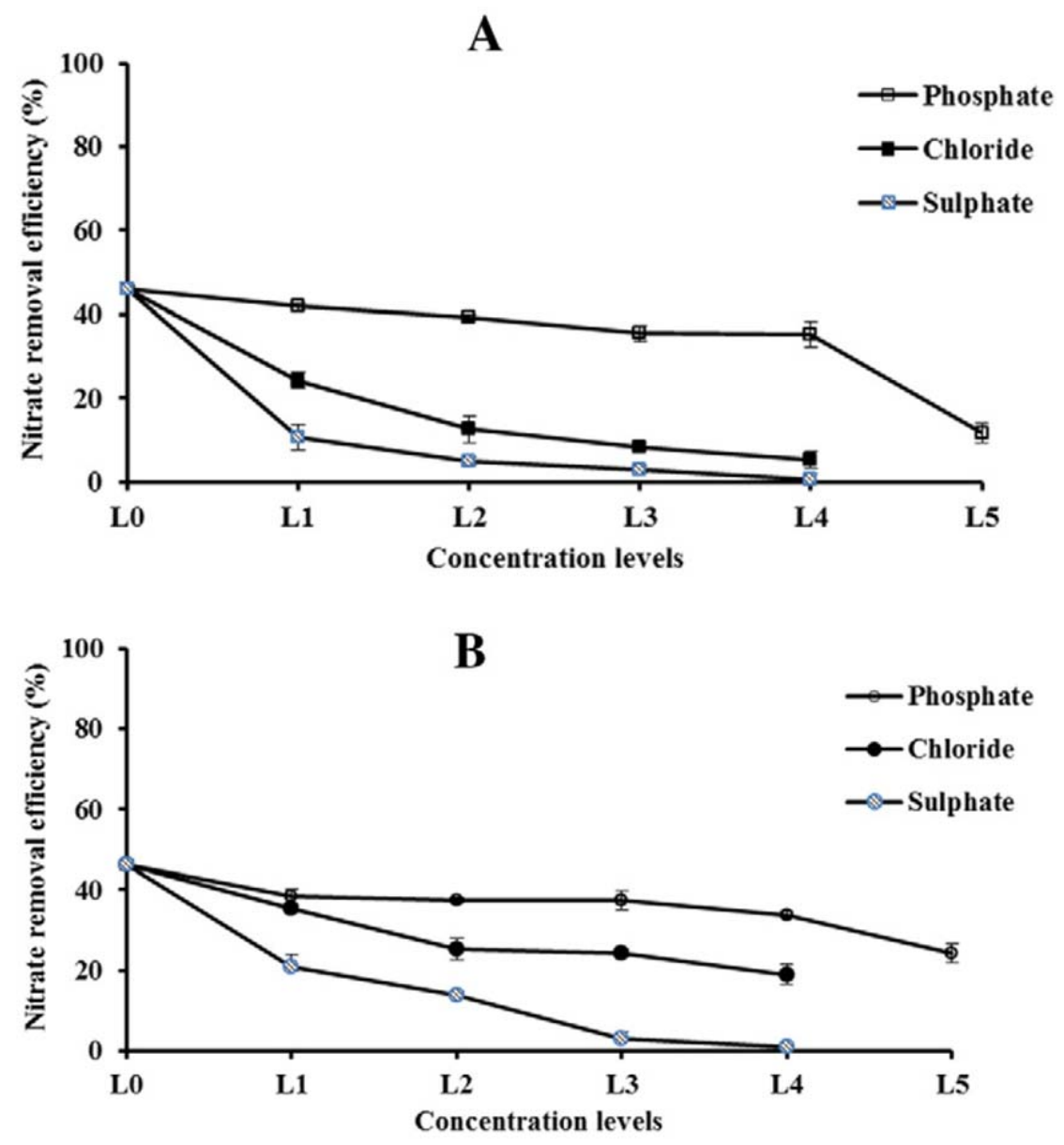
Fig. 3. Effect of complementary ions on the removal of nitrate by (A) AG corn cob, and (B) AG coconut copra (initial nitrate concentration $20 \mathrm{mg} \mathrm{N} / \mathrm{L}$ ). L1, L2, L3, and L4 for sulphate chloride and sulphate are 20,30, 50, and $70 \mathrm{mg} \mathrm{Cl}$ or S/L. For phosphate L1, L2, L3, L4, and L5 represent $0.5,1,5,10$, and $30 \mathrm{mg} \mathrm{P} / \mathrm{L}$. Vertical bars on the graphs represent standard errors of means of the data points.

\subsection{Adsorption kinetics}

The study on the adsorption kinetics was conducted to predict the rate of nitrate removal by the adsorbents. The data was fitted to pseudo-first order, pseudo-second order and Elovich models and the values for the model parameters are given in Table 4. Of the three models, the Elovich model fitted the data well for both the AG adsorbents $\left(\mathrm{R}^{2}=0.96-0.97\right)$, whereas the PFO and PSO models' fits to data were poor $\left(\mathrm{R}^{2}=0.46-0.81\right)$. The reason for the good fit of data to Elovich model is that this model is applicable to kinetics of adsorption of solutes on heterogeneous surfaces with variation of adsorption energies (Özacar and Şengil, 2005 and Riahi et al., 2013). The surfaces of the agricultural wastes being heterogeneous (Riahi et al., 2013), this model was found to describe the adsorption kinetics very well.

Table 4. Batch adsorption kinetic parameters for the pseudo-first order (PFO) and pseudosecond order (PSO) models fit to the adsorption of nitrate on AG corn cob and AG coconut copra.

\begin{tabular}{llll}
\hline Models & Parameters & AG corn cob & AG coconut copra \\
\hline PFO & $q_{\text {exp }}$ & 11.1 & 11.5 \\
& $\mathrm{q}_{\mathrm{e}}(\mathrm{mg} \mathrm{N} / \mathrm{g})$ & 10.3 & 10.4 \\
& $\mathrm{k}_{1}(/ \mathrm{h})$ & 19 & 14.8 \\
& $\mathrm{R}^{2}$ & 0.5208 & 0.4557 \\
PSO & $\mathrm{q}_{\mathrm{e}}(\mathrm{mg} \mathrm{N} / \mathrm{g})$ & 10.7 & 11.1 \\
& $\mathrm{k}_{2}(\mathrm{~g} / \mathrm{mg} \mathrm{h})$ & 3.7 & 2.11 \\
\multirow{2}{*}{ Elovich } & $\mathrm{R}^{2}$ & 0.8132 & 0.7654 \\
& $\beta(\mathrm{g} / \mathrm{mg})$ & 1.33 & 0.91 \\
& $\alpha(\mathrm{mg} / \mathrm{g} \mathrm{min})$ & 10,886 & 250 \\
& $\mathrm{R}^{2}$ & 0.9707 & 0.9604 \\
\hline
\end{tabular}

\subsection{Fixed-bed adsorption experiment}

\subsubsection{Nitrate adsorption with and without complementary ions}

Synthetic solutions were used for this study as in the case of the batch studies. However, the concentrations of nitrate and the complementary ions, phosphate and sulphate used were similar to those generally found in contaminated ground and wastewaters as stated earlier in this paper. The breakthrough curves for the nitrate adsorption on AG and unmodified corncob and coconut copra at the influent concentration of $20 \mathrm{mg} \mathrm{N} / \mathrm{L}$ are given in Fig. 4. The breakthrough curves for the unmodified adsorbents reached the adsorption saturation level faster ( $2 \mathrm{~h}$ and $3 \mathrm{~h}$ for the corn cob and coconut copra, respectively) than the curves for the $\mathrm{AG}$ adsorbents (12 $\mathrm{h}$ and $14 \mathrm{~h}$ for $\mathrm{AG}$ corn cob and AG coconut copra, respectively). This is 
due to the higher number of adsorption sites in the AG materials compared to the unmodified materials as explained under batch studies results.
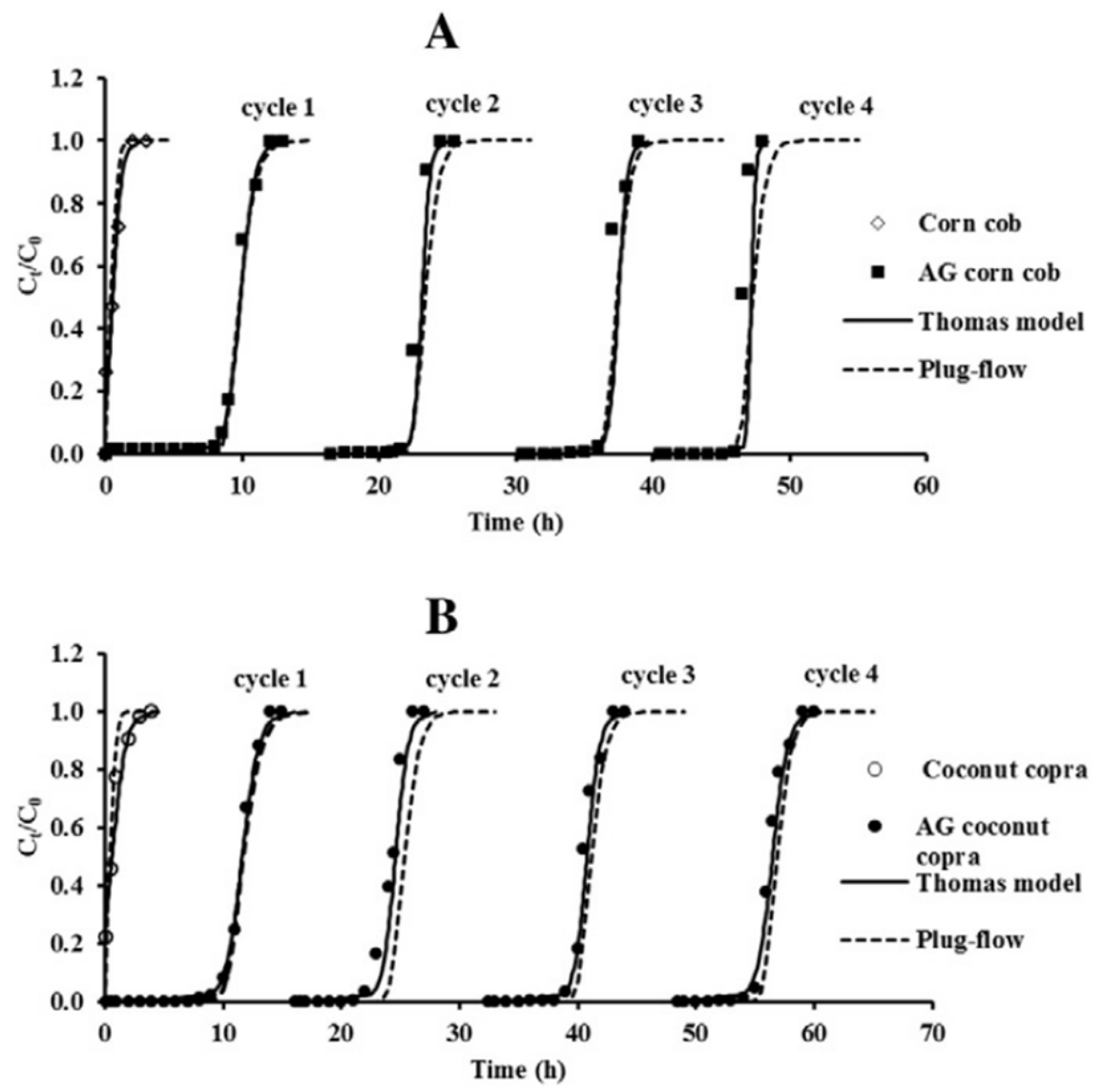

Fig. 4. Breakthrough curves for nitrate adsorption on AG (for 4 adsorption/desorption cycles) and unmodified (A) corn cob and (B) coconut copra (nitrate only in influent solution.

The adsorption capacities were calculated from the breakthrough curves manually (Eq.1) and are shown in Table 5. Consistent with the batch adsorption results, the fixed-bed adsorption capacities for the AG adsorbents were very much higher than the unmodified adsorbents. While the AG corn cob adsorption capacity up to the saturation time of $12 \mathrm{~h}$ (400 bed volumes; bed volume $=$ flow velocity $(\mathrm{m} / \mathrm{h}) *$ time $(\mathrm{h}) /$ bed height $(\mathrm{m}))$ was $15.3 \mathrm{mg} \mathrm{N} / \mathrm{g}$, the unmodified corn cob up to the saturation time of $2 \mathrm{~h}$ ( 66 bed volume) was $0.6 \mathrm{mg} \mathrm{N} / \mathrm{g}$. The AG coconut copra adsorption capacity was a little higher than that of the AG corn cob and was $18.6 \mathrm{mg} \mathrm{N} / \mathrm{g}$ up to $14 \mathrm{~h}$ (460 bed volume) and $0.9 \mathrm{mg} \mathrm{N} / \mathrm{g}$ for up to $3 \mathrm{~h}$ (100 bed volume) for the unmodified coconut copra. The fixed-bed adsorption capacities were lower than the batch Langmuir adsorption capacities, because in the batch experiments, adsorption reached equilibrium and Langmuir model predicted the maximum adsorption capacity at high nitrate concentration unlike in the fixed-bed experiment, where adsorption capacity was measured at a lower concentration of $20 \mathrm{mg} \mathrm{N} / \mathrm{L}$. Another reason for the lower nitrate adsorption capacity in the column experiment is the use of tap water in this experiment where the presence of chloride $(30 \mathrm{mg} / \mathrm{L})$ may have competed with nitrate for adsorption. In the batch experiment Milli-Q water with negligible concentrations of anions was used. 
Table 5. Nitrate adsorption capacity of AG and unmodified corn cob and coconut copra and percentage of nitrate desorbed for different adsorption/desorption cycles.a

\begin{tabular}{|c|c|c|c|c|c|c|c|c|c|}
\hline Adsorbents & Feed concentration & $\begin{array}{l}\text { Number of } \\
\text { adsorption- } \\
\text { desorption } \\
\text { cycles }\end{array}$ & $\begin{array}{c}\text { Adsorption } \\
\text { bed } \\
\text { volumes }^{\mathrm{a}}\end{array}$ & $\begin{array}{c}\begin{array}{c}\text { Adsorption } \\
\text { capacity }\end{array} \\
(\mathrm{mg} \mathrm{N} / \mathrm{g})\end{array}$ & $\begin{array}{l}\text { Amount } \\
\text { of } \mathbf{N} \\
\text { adsorbed } \\
\text { (mg) }\end{array}$ & $\begin{array}{c}\text { Amount } \\
\text { of } N \\
\text { desorbed } \\
\text { (mg) }\end{array}$ & $\begin{array}{c}\% \\
\text { Desorbed }\end{array}$ & $\begin{array}{c}\text { Desorption } \\
\text { bed } \\
\text { volumes }^{\mathrm{a}}\end{array}$ & $\begin{array}{c}\text { Desorption } \\
\% \text { at half } \\
\text { the bed } \\
\text { volumes }^{\mathrm{a}}\end{array}$ \\
\hline Corn cob & $20 \mathrm{mgN} / \mathrm{L}$ & 1 & 66 & 0.6 & 11 & 10 & 83.9 & 16 & 72 \\
\hline \multirow{6}{*}{$\begin{array}{l}\text { AG corn } \\
\text { cob }\end{array}$} & $20 \mathrm{mgN} / \mathrm{L}$ & 1 & 400 & 15.3 & 307 & 305 & 99.9 & 40 & 78 \\
\hline & & 2 & 300 & 11.3 & 227 & 224 & 99.2 & 35 & 84 \\
\hline & & 3 & 300 & 10.7 & 215 & 215 & 99.9 & 35 & 86 \\
\hline & & 4 & 300 & 10.7 & 213 & 212 & 99.6 & 35 & 86 \\
\hline & $20 \mathrm{mgN} / \mathrm{L}+5 \mathrm{mgP} / \mathrm{L}$ & 1 & 315 & 12.7 & 255 & 242 & 95.1 & 33 & 81 \\
\hline & $20 \mathrm{mgN} / \mathrm{L}+50 \mathrm{mgS} / \mathrm{L}$ & 1 & 132 & 3.9 & 79 & 70 & 88.9 & 25 & 83 \\
\hline $\begin{array}{l}\text { Coconut } \\
\text { copra }\end{array}$ & $20 \mathrm{mgN} / \mathrm{L}$ & 1 & 100 & 0.9 & 17 & 15 & 84.6 & 16 & 74 \\
\hline \multirow{6}{*}{$\begin{array}{l}\text { AG } \\
\text { coconut } \\
\text { copra }\end{array}$} & $20 \mathrm{mgN} / \mathrm{L}$ & 1 & 460 & 18.6 & 372 & 366 & 98.3 & 40 & 76 \\
\hline & & 2 & 360 & 12.9 & 259 & 251 & 96.9 & 40 & 80 \\
\hline & & 3 & 360 & 12.5 & 251 & 250 & 99.8 & 40 & 84 \\
\hline & & 4 & 360 & 11.6 & 232 & 231 & 99.3 & 40 & 84 \\
\hline & $20 \mathrm{mgN} / \mathrm{L}+5 \mathrm{mgP} / \mathrm{L}$ & 1 & 365 & 14.1 & 282 & 274 & 97.2 & 33 & 79 \\
\hline & $20 \mathrm{mgN} / \mathrm{L}+50 \mathrm{mgS} / \mathrm{L}$ & 1 & 165 & 5.7 & 114 & 107 & 93.8 & 25 & 82 \\
\hline
\end{tabular}

a Bed volume $=$ Flow velocity $(\mathrm{m} / \mathrm{h}) *$ time $(\mathrm{h}) /$ bed height $(\mathrm{m})$.

In the presence of complementary ions the complete breakthrough occurred at $1 \mathrm{~h}, 5 \mathrm{~h}$ and $8 \mathrm{~h}$ for the $\mathrm{N}+\mathrm{S}, \mathrm{N}+\mathrm{P}$ and $\mathrm{N}$ feed, respectively, for the AG corn cob and $3 \mathrm{~h}, 6 \mathrm{~h}$ and $9 \mathrm{~h}$ for the AG coconut copra. The results showed that, when the complementary ions are present in the water less time was needed to reach saturation in the fixed-bed due to reduction in the nitrate's adsorption capacity. The sulphate ion competed most with nitrate adsorption resulting in a significant reduction in nitrate adsorption capacity as observed in batch studies. This is because it has more negative charges.

\subsubsection{Nitrate desorption and adsorbent regeneration}

The regeneration of the adsorbents was carried out by leaching the adsorbed nitrate from the fixed-bed by $1 \mathrm{M} \mathrm{KCl}$ solution at a flow rate of $26.6 \mathrm{~mL} / \mathrm{min}$ to desorb the nitrate from the adsorbents and determine whether the adsorbents can be reused. Results showed that the high concentration of chloride ions displaced the nitrate from the adsorption sites. Four adsorption-desorption cycles were conducted for the influent solution containing nitrate alone 
(Fig. 4). 97-100\% of the adsorbed nitrate was desorbed during the adsorption-desorption cycles for the AG corn cob and AG coconut copra adsorbents (Table 5). The number of bed volumes of $1 \mathrm{M} \mathrm{KCl}$ required for desorption of nitrate was 35-40 compared to the number of bed volumes required for adsorption of 300-460 (Table 5). This means the desorbed solution was about 10 times concentrated than the influent nitrate concentration. When the volume of the desorbing $\mathrm{KCl}$ solution was reduced to half (16 bed volumes), the amount of nitrate desorbed was still high at $76-86 \%$ (Table 5). Thus the cost of the desorbing reagent can be cut down by half with only $20-30 \%$ reduction in desorption. Chloride concentration in the desorbed solution is also cut down by half which may cause less or no damage to crops if the desorbed solution is used as nitrate fertiliser. The nitrate adsorption capacity dropped by approximately $30 \%$ in the second cycle and then marginally decreased thereafter for each cycle for both the adsorbents. Thus, the AG corn cob and coconut copra can be reused several times by maintaining good adsorption capacity for nitrate adsorption, reducing operational costs. Alternatively, the used bio adsorbents can be used as fertiliser. The nitrate in the desorbed solution can be used in fertigation to supply nitrogen to plants. The $\mathrm{K}$ in the desorbed solution will also benefit plants.

\subsubsection{Fixed-bed column modelling}

To properly design the adsorption process, one needs to clearly understand the relationship between the adsorption equilibrium, intra particle diffusion and hydrodynamic condition of the fixed-bed column. In this work, the axially dispersed plug-flow model with several correlation parameters were used to predict the fixed-bed column behaviour. In addition, the Freundlich isotherm parameters (Table 3) were used to explain the adsorption equilibrium at solid/liquid interfaces.

The main parameters controlling the fixed-bed adsorption characteristics are axial dispersion and the external film mass transfer coefficients. Regarding axial dispersion, the adsorption front axially increases due to flow in the inter particle voids. It is derived from the contribution of the molecular diffusion and dispersion caused by the fluid flow. The adsorbate diffuses from the bulk liquid phase to the stagnant boundary layer of the adsorbent external surface which is referred to as the film mass transfer. The axially dispersion coefficient $\left(\mathrm{D}_{\mathrm{L}}\right)$ parameter values determined using equation 2 were $3.5 \times 10^{-6}$ and $3.4 \times 10^{-6} \mathrm{~m} / \mathrm{s}$ for the $\mathrm{AG}$ corn cob and $\mathrm{AG}$ coconut copra, respectively, for the first adsorption/desorption cycle. The film mass transfer coefficient $\left(\mathrm{k}_{\mathrm{f}}\right)$ values were obtained using equation 3. These values were $4.3 \times 10^{-3}$ and $2.2 \times 10^{-3} \mathrm{~m} / \mathrm{s}$ for the AG corn cob and AG coconut copra, respectively, for the first adsorption-desorption cycle. The surface diffusion coefficient $\left(D_{S}\right)$ was determined by matching the simulation values with the experimental adsorption values obtained from the breakthrough curve. The $\mathrm{D}_{\mathrm{s}}$ values for the corn cob and AG corn cob were $1.96 \times 10^{-9}$ and $1.64 \times 10^{-10} \mathrm{~m}^{2} / \mathrm{s}$, respectively, and $1.58 \times 10^{-9}$ and $1.28 \times 10^{-10} \mathrm{~m}^{2} / \mathrm{s}$ for the coconut copra and AG coconut copra, respectively, for the first adsorption/desorption cycle.

To predict the adsorption breakthrough curves for the 2nd to the 4th adsorption/desorption cycles, the assumption was further taken that the parameter values are the same for all the 
cycles, even though adsorption capacity of the AG materials for the 2nd to 4th cycles decreased around $20-30 \%$ of the 1 st cycle. The model parameters $D_{s}, k_{f}$ and $D_{L}$ depend on the influent concentration and/or filtration velocity which are the same for all the cycles. Therefore the assumption that the parameter values are same for all the cycles is reasonable.

As shown in Fig. 4, the axially dispersed plug-flow model reasonably fitted the adsorption breakthrough curve patterns, even though some deviations were observed for the 2nd to 4th cycles, probably because the adsorption capacity decreased from the values of the first cycle and the ratio of the adsorption capacity decrease was utilised in the model prediction. In comparison to this finding, our recent study on nitrate adsorption by Fe-coated Dowex ion exchange resin showed that the adsorption capacity remained nearly the same during three adsorption/desorption cycles and plug-flow model satisfactorily fitted to the data of all the three cycles (Kalaruban et al., 2016).

The empirical Thomas model was also used to predict the fixed-bed experimental results. The model equation and the parameter values are given in Table 1 and Table 6 , respectively. This model fit to the data was better than that of axially dispersed plug-flow model, especially for the second cycle onwards. The Thomas model adsorption capacities $\left(\mathrm{q}_{0}\right)$ agreed well with the adsorption capacities, calculated manually from the breakthrough curve (Table 6).

Table 6. Thomas model parameters for the adsorption of nitrate ion in fixed-bed containing corn cob, coconut copra, AG corn cob and AG coconut copra for different adsorptiondesorption cycles.

\begin{tabular}{|c|c|c|c|c|c|c|c|c|c|c|c|}
\hline \multirow[t]{2}{*}{ Models } & \multirow[t]{2}{*}{ Parameters } & \multirow{2}{*}{$\begin{array}{l}\begin{array}{l}\text { Corn } \\
\text { cob }\end{array} \\
1 \text { st } \\
\text { cycle }\end{array}$} & \multicolumn{4}{|c|}{ AG corn cob } & \multirow{2}{*}{$\begin{array}{l}\begin{array}{l}\text { Coconut } \\
\text { copra }\end{array} \\
1 \text { st cycle }\end{array}$} & \multicolumn{4}{|c|}{ AG coconut copra } \\
\hline & & & $\begin{array}{l}1 \text { st } \\
\text { cycle }\end{array}$ & $\begin{array}{l}\text { 2nd } \\
\text { cycle }\end{array}$ & $\begin{array}{l}3 \text { rd } \\
\text { cycle }\end{array}$ & $\begin{array}{l}\text { 4th } \\
\text { cycle }\end{array}$ & & $\begin{array}{l}1 \mathrm{st} \\
\text { cycle }\end{array}$ & $\begin{array}{l}\text { 2nd } \\
\text { cycle }\end{array}$ & $\begin{array}{l}3 \text { rd } \\
\text { cycle }\end{array}$ & $\begin{array}{l}\text { 4th } \\
\text { cycle }\end{array}$ \\
\hline \multirow[t]{3}{*}{$\begin{array}{l}\text { Thomas } \\
\text { model }\end{array}$} & $\begin{array}{l}\mathrm{k}_{\mathrm{TH}} \\
(\mathrm{ml} / \mathrm{minmg})\end{array}$ & 2.58 & 1.59 & 2.84 & 2.46 & 5.15 & 1.45 & 1.19 & 1.53 & 1.54 & 1.28 \\
\hline & $\mathrm{q}_{0}(\mathrm{mgN} / \mathrm{g})$ & 0.83 & 15.4 & 10.34 & 10.88 & 10.41 & 0.95 & 18.12 & 12.76 & 13.71 & 13.2 \\
\hline & $\mathrm{R}_{2}$ & 0.974 & 0.9825 & 0.9624 & 0.9623 & 0.9669 & 0.9921 & 0.9786 & 0.9832 & 0.9584 & 0.9717 \\
\hline
\end{tabular}

\section{Conclusions}

Amine-grafted (AG) biosorbents such as corn cob and coconut copra are very effective in removing nitrate from water. They have adsorption capacities many times higher than those of the respective unmodified materials. The Langmuir maximum adsorption capacities (mg N/g) of AG corn cob (50) and coconut copra (59) are also higher than many of the other amine-grafted biosorbents (11-17) and commercially available ion exchange resins (28-39) reported in literature. They are attractive low-cost biosorbents that can be used in many countries, especially in rural areas where large quantities of these wastes are produced. The used adsorbents can be directly applied to lands as nitrate fertilisers and the desorbed nitrate 
solution containing $\mathrm{K}$ can be used in fertigation to supply nutrients ( $\mathrm{N}$ and $\mathrm{K}$ ) to plants. Mathematical models developed for fixed-bed column mode adsorption behaviour can be successfully used in designing full-scale treatment plant. It is recommended that this study with synthetic solutions be extended to real ground and surface waters contaminated with nitrate.

\section{Acknowledgements}

This study was financially supported by the Cooperative Research Centre for Contamination Assessment and Remediation of the Environment (CRC CARE) (project number4.1.1713/14). We thank Mr. Phillip Thomas in Adelaide, South Australia for proof-reading/editing this paper.

\section{References}

Akan, J.C., Abbagambo,M.T., Chellube, Z.M., Abdulrahman, F.I., 2012. Assessment of pollutants in water and sediment samples in Lake Chad, Baga, North Eastern Nigeria. J. Environ. Protect. 3, 1428-1441.

Bae, B.U., Jung, Y.H., Han, W.W., Shin, H.S., 2002. Improved brine recycling during nitrate removal using ion exchange. Water Res. 36, 3330-3340.

Bhatnagar, A., Sillanpää, M., 2011. A review of emerging adsorbents for nitrate removal from water. Chem. Eng. J. 168, 493-504.

Bhatnagar, A., Vilar, V.J.P., Botelho, C.M.S., Boaventura, R.A.R., 2010. Coconut-based biosorbents for water treatment - a review of the recent literature. Adv. Colloid Interf. Sci. $160,1-15$.

Camargo, J.A., Alonso, Á., 2006. Ecological and toxicological effects of inorganic nitrogen pollution in aquatic ecosystems: a global assessment. Environ. Int. 32, 831-849.

Chatterjee, S., Lee, D.S., Lee, M.W., Woo, S.H., 2009. Nitrate removal from aqueous solutions by cross-linked chitosan beads conditioned with sodium bisulfate. J. Hazard. Mater. $166,508-513$.

Chung, S., Wen, C.Y., 1968. Longitudinal dispersion of liquid flowing through fixed and fluidized beds. AlChE J. 14, 857-866.

Deng, S., Niu, L., Bei, Y.,Wang, B., Huang, J., Yu, G., 2013. Adsorption of perfluorinated compounds on aminated rice husk prepared by atom transfer radical polymerization.

Chemosphere 91, 124-130.

Fewtrell, L., 2004. Drinking-water nitrate, methemoglobinemia, and global burden of disease: a discussion. Environ. Health Perspect. 1371-1374.

Ioannidou, O., Zabaniotou, A., Antonakou, E., Papazisi, K., Lappas, A., Athanassiou, C., 2009. Investigating the potential for energy, fuel, materials and chemicals production from corn residues (cobs and stalks) by non-catalytic and catalytic pyrolysis in two reactor configurations. Renew. Sust. Energ. Rev. 13, 750-762. 
Kalaruban, M., Loganathan, P., Shim, W., Kandasamy, J., Naidu, G., Nguyen, T.V., Vigneswaran, S., 2016. Removing nitrate from water using iron-modified Dowex 21K XLT ion exchange resin: batch and fluidised-bed adsorption studies. Sep. Purif. Technol. 158, 6270.

Kapoor, A., Viraraghavan, T., 1997. Nitrate removal from drinking water - review. J. Environ. Eng. 123, 371-380.

Kim, T.Y., An, S.S., Shim, W.G., Lee, J.W., Cho, S.Y., Kim, J.H., 2015. Adsorption and energetic heterogeneity properties of cesium ions on ion exchange resin. J. Ind. Eng. Chem. $260-267$.

Loganathan, P., Vigneswaran, S., Kandasamy, J., 2013. Enhanced removal of nitrate from water using surface modification of adsorbents — a review. J. Environ. Manag. 131, 363374.

Loganathan, P., Vigneswaran, S., Kandasamy, J., Bolan, N.S., 2014. Removal and recovery of phosphate from water using sorption. Crit. Rev. Environ. Sci. Technol. 44, 847-907.

Luna, F.M.T., Araújo, C.C., Veloso, C.B., Silva Jr., I.J., Azevedo, D.C., Cavalcante Jr., C.L., 2011. Adsorption of naphthalene and pyrene from isooctane solutions on commercial activated carbons. Adsorption 17, 937-947.

Nelder, J.A., Mead, R., 1965. A simplex method for function minimization. Comput. J. 7, $308-313$.

NHMRC, 2011. Australia Drinking Water Guidelines 6. National Water Quality Management Strategy vol. 1. National Health and Medical Research Council, Commonwealth of Australia, Canberra.

Nur, T., Loganathan, P., Nguyen, T., Vigneswaran, S., Singh, G., Kandasamy, J., 2014. Batch and column adsorption and desorption of fluoride using hydrous ferric oxide: solution chemistry and modeling. Chem. Eng. J. 247, 93-102.

Nur, T., Shim, W., Loganathan, P., Vigneswaran, S., Kandasamy, J., 2015. Nitrate removal using Purolite A520E ion exchange resin: batch and fixed-bed column adsorption modelling. Int. J. Environ. Sci. Technol. 1311-1320.

Oladoja, N., Helmreich, B., 2014. Batch defluoridation appraisal of aluminium oxide infused diatomaceous earth. Chem. Eng. J. 258, 51-61.

Oladoja, N.A., Ahmad, A.L., 2013. Gastropod shell as a precursor for the synthesis of binary alkali-earth and transition metal oxide for $\mathrm{Cr}$ (VI) abstraction from aqua system. Sep. Purif. Technol. 116, 230-239.

Orlando, U.S., Baes, A.U., Nishijima, W., Okada, M., 2002a. Preparation of agricultural residue anion exchangers and its nitrate maximum adsorption capacity. Chemosphere 48, 1041-1046. 
Orlando, U.S., Baes, A.U., Nishijima,W., Okada, M., 2002b. A newprocedure to produce lignocellulosic anion exchangers from agricultural waste materials. Bioresour. Technol. 83, 195-198.

Özacar, M., Şengil, İ.A., 2005. A kinetic study of metal complex dye sorption onto pine sawdust. Process Biochem. 40, 565-572.

Pan, B., Wu, J., Pan, B., Lv, L., Zhang, W., Xiao, L.,Wang, X., Tao, X., Zheng, S., 2009. Development of polymer-based nanosized hydrated ferric oxides (HFOs) for enhanced phosphate removal from waste effluents. Water Res. 43, 4421-4429.

Riahi, K., Chaabane, S., Thayer, B.B., 2013. A kinetic modeling study of phosphate adsorption onto Phoenix dactylifera L. date palm fibers in batch mode. J. Saudi Chem. Soc. (In Press).

Shah, D., Trivedi, P., 2011. Pysico-chemical analysis of bore wells and open wells drinking water of, Kathalal region. Curr. World Environ 6, 287-290.

Samatya, S., Kabay, N., Yüksel, Ü., Arda, M., Yüksel, M., 2006. Removal of nitrate from aqueous solution by nitrate selective ion exchange resins. React. Funct. Polym. 66, 12061214.

Somasundaram,M.V., Ravindran, G., Tellam, J.H., 1993. Ground-water pollution of the Madras urban aquifer, India. Ground Water 31, 4-11.

Song, H., Zhou, Y., Li, A., Mueller, S., 2012. Selective removal of nitrate from water by a macroporous strong basic anion exchange resin. Desalination 296, 53-60.

Villadsen, J., Stewart,W., 1967. Solution of boundary-value problems by orthogonal collocation. Chem. Eng. Sci. 22, 1483-1501.

Wakao, N., Funazkri, T., 1978. Effect of fluid dispersion coefficients on particle-to-fluid mass transfer coefficients in packed beds: correlation of sherwood numbers. Chem. Eng. Sci. $33,1375-1384$.

WHO, 2011. Guidlines for Drinking-water Quality. fourth Ed.World Health Organization, Gewneva, Switzerland.

Xing, X., Gao, B., Zhong, Q., Yue, Q., Li, Q., 2011. Sorption of nitrate onto aminecrosslinked wheat straw: characteristics, column sorption and desorption properties. J. Hazard. Mater. 186, 206-211.

Xu, X., Gao, B., Yue, Q., Zhong, Q., 2010. Preparation of agricultural by-product based anion exchanger and its utilization for nitrate and phosphate removal. Bioresour. Technol. $101,8558-8564$.

Xu, X., Gao, B.Y., Zhao, Y., Chen, S., Tan, X., Yue, Q., Lin, J.,Wang, Y., 2012. Nitrate removal from aqueous solution by Arundo donax L. reed based anion exchange resin. J. Hazard. Mater. 203-204, 86-92. 
Yao, Y., Gao, B., Inyang,M., Zimmerman, A.R., Cao, X., Pullammanappallil, P., Yang, L., 2011. Biochar derived from anaerobically digested sugar beet tailings: characterization and phosphate removal potential. Bioresour. Technol. 102, 6273-6278. 